\title{
Pengaruh Konflik Rumah Tangga Terhadap Karakter Anak
}

\author{
Marsi Bombongan Rantesalu ${ }^{1^{*}}$, Albert Timuneno ${ }^{2}$ \\ Institut Tinggi Agama Kristen Negeri Kupang \\ Mahasiswa Institut Tinggi Agama Kristen Negeri Kupang \\ *marsibombongan@gmail.com
}

\begin{abstract}
Domestic conflict is a problem where husband and wife are fixing problems in their marriage. In the household as a forum for interaction between parents and children can influence the good behavior of the child's character. The purpose of this study was to find out about household conflict with the character of children in the GMIT Betania Nevo Klasis Amarasi Barat. The method used in this study is a survey technique using quantitative. The population in this study were members of the GMIT Betania Nevo Klasis Amarasi Barat with a total sample of 44 people. Data collection was carried out by questionnaire and data obtained from the results of the study were analyzed with statistical procedures and techniques. Based on the results of the analysis in this study, it was found that the difference between the house and the character of children in the GMIT Betania Nevo Klasis Amarasi Barat was 46.4\% and the rest was used by other factors.
\end{abstract}

Keywords: Conflict, Household, Character, Child

\begin{abstract}
Abstrak: Konflik rumah tangga merupakan keadaan dimana suami dan istri sedang mengalami masalah dalam perkawinannya yang mengakibatkan perilaku mereka yang cenderung kurang harmonis. Dalam sebuah rumah tangga sebagai wadah interaksi antara orang tua dan anak dapat memberi pengaruh terhadap perilaku maupun karakter anak. Tujuan dari penelitian ini adalah mencari tahu seberapa besar pengaruh konflik rumah tangga terhadap karakter anak khususnya yang ada di Jemaat GMIT Betania Nevo Klasis Amarasi barat. Peneliti dalam penelitian ini menggunakan teknik survei dengan pendekatan kuantitatif. Populasi dalam penelitian ini adalah Anggota Jemaat GMIT Betania Nevo Klasis Amarasi Barat dengan menggunakan sampel yaitu 44 orang. Pengumpulan data menggunakan angket yang telah diuji validitas dan reliebilitasnya dan data-data yang terkumpul dari hasil penelitian kemudian dianalisis menggunakan tahap-tahap dan teknik statistika. Berdasarkan hasil analisis dalam penelitian ini ditemukan adanya pengaruh antara konflik rumah tanga dengan karakter anak di jemaat GMIT Betania Nevo Klasis Amarasi Barat sebesar 46,4 \% dan selebihnya dipengaruhi oleh factorfaktor lain.
\end{abstract}

Kata kunci: konflik, rumah tangga, karakter, anak

\begin{tabular}{llll}
\hline Article History : & Received: 29-05-2020 & Revised: 21-06-2020 & Accepted: 23-06-2020
\end{tabular}

\section{Pendahuluan}

Konflik keluarga atau konflik dalam rumah tangga merupakan pergumulan hampir seluruh insan yang telah memutuskan membangun komitmen bersama dalam 
sebuah rumah tangga. Tidak terlepas dari situ adalah keluarga Kristen yang di klaim sebagai suatu ikatan sekali seumur hidup. Sebuah tanggung jawab besar untuk mempertahankan sebuah hubungan rumah tangga yang harmonis di tengah banyaknya gelombang permasalahan yang bisa menghantam bahtera rumah tangga kristen. Tak jarang suami atau istri dengan usahanya mnyelesaikan masalah dalam keluarga tetapi masalah itu tetap ada. Hal ini terjadi karena di dalam hati setiap individu terdapat benih konflik. ${ }^{1}$

Konflik dalam rumah tangga merupakan keadaan krisis yang mana dapat diartikan sebagai kondisi dimana relasi antar individu dalam ikatan itu menjadi kacau, tidak ada keteraturan yang menyebabkan hilangnya wibawa sebagai orang tua. Permasalahan tersebut dapat menimbulkan terjadinya komunikasi yang tidak efektif antara anggota keluarga yang mengakibatkan kesalah pahaman yang muaranya pada pertengkaran yang melibatkan suami dan istri ataukah ketidakcocokan antara orang tua dengan anak-anaknya. Menurut Finchman, konflik rumah tangga merupakan sebuah keadaan dimana suami dan istrinya sedang mengalami suatu permasalah di dalam hubungan perkawinannya kemudian hal itu tercermin melalui perilaku yang cenderung terlihat tidak harmonis. ${ }^{2}$

Penyebab konflik dalam rumah tangga ditengarai oleh berbagai persoalan, yang muncul dari keluarga itu sendiri dan juga persoalan yang bisa bersumber dari luar. Kurang membangun komunikasi yang baik yang dilakukan oleh suami istri atau kurangnya komunikasi yang dibangun antara orang tua dan anaknya bisa menjadi pemicu permasalahan. ${ }^{3}$ Keutuhan keluarga juga akan hancur jika tidak adalagi ketundukan dari seorang istri dan kasih sejati dari suami (Kolose 3:18-19). ${ }^{4}$ Seorang istri yang tidak cakap dan bijak dalam membina keluarganya juga bisa menjadi faktor penyebab konflik dalam keluarga. ${ }^{5}$ Yang paling sering menjadi penyebab retaknya sebuah rumah tangga karena terjadinya kekerasan dalam rumah tangga. ${ }^{6}$

\footnotetext{
1 Dessy Christina and Andik Matulessy, “Penyesuaian Perkawinan, Subjective Well Being Dan Konflik Perkawinan," Persona:Jurnal Psikologi Indonesia 5, no. 01 (January 12, 2016), accessed May 28, 2020, http://jurnal.untag-sby.ac.id/index.php/persona/article/view/737.

${ }^{2}$ Fincham, F.D, Stability and Change in Relationships (Boston: Cambridge University Press, 2002).

${ }^{3}$ Naomi Sampe, "Meretas Kecakapan Komunikasi Interpersonal Keluarga Kristen Memasuki Era 4.0," BIA': Jurnal Teologi dan Pendidikan Kristen Kontekstual 2, no. 1 (June 24, 2019): 72-82, accessed May 28, 2020, http://www.jurnalbia.com/index.php/bia/article/view/84.

${ }^{4}$ Sumaeli Gea, "Konsep Tunduk Dan Mengasihi Berdasarkan Kolose 3:18-19 Sebagai Landasan Bagi Keutuhan Rumah Tangga Kristen Di GPdI Filadelfia," Voice of HAMI: Jurnal Teologi dan Pendidikan Agama Kristen 2, no. 1 (October 22, 2019): 60-77, accessed May 28, 2020, http://stthami.ac.id/ojs/index.php/hami/article/view/6.

5 Fereddy Siagian, "Figur Istri Yang Bijak Dalam Membina Rumah Tangga Kristen Bahagia Menurut Amsal 31:10-30 | Syntax Literate ; Jurnal Ilmiah Indonesia” (n.d.), accessed May 28, 2020, http://www.jurnal.syntaxliterate.co.id/index.php/syntax-literate/article/view/832.

${ }^{6}$ Abu Hanifah, "PERMASALAHAN KEKERASAN DALAM RUMAH TANGGA DAN ALTERNATIF PEMECAHANNYA,” Sosio Konsepsia 12, no. 3 (April 10, 2017): 45-56, accessed May 28, 2020, https://ejournal.kemsos.go.id/index.php/SosioKonsepsia/article/view/640.
} 
Setiap ada konflik selalu menimbulkan dampak yang negatif. Demikian adanya dengan konflik yang terjadi dalam sebuah rumah tangga, tak pelak yang menjadi korban paling nyata adalah anak-anak. Konflik rumah tangga dapat menyebabkan depresi pada anak yang kemudian berpengaruh signifikan terhadap prestasinya. ${ }^{7}$ Selain itu anak-anak dapat mengalami trauma secara psikis. ${ }^{8}$ Masalah dalam keluarga juga berpengaruh kepada mental seseorang. ${ }^{9}$ Dalam sebuah rumah tangga sebagai wadah interaksi sejumlah orang, juga memberikan pengaruh yang signifikan terhadap perilaku maupun karakter anak. Karakter yang dimaksudkan disini adalah sifat, tabiat, atau watak tertentu yang membedakan seseorang dengan orang lain. ${ }^{10}$ Keluarga merupakan pemegang peranan besar dalam perkembangan anak termasuk karakternya. Keluarga merupakan tempat belajar anak secara konkrit dan juga secara paktis, kelaurga merupakan sekolah yang terbaik untuk seorang anak. Pendidikan formal tidak dapat menggantikan peranan keluarga, fondasinya ada di dalam keluarga di luar itu merupakan pelengkap. ${ }^{11}$

Anak-anak yang memiliki karakter yang bermasalah dapat terlihat dari ciri-ciri yang dimilikinya, antara lain: 1) Susah diatur dan diajak kerjasama, dalam hal ini terlihat pada anak tersebut kebiasaan melawan dan melakukan sesuatu dengan kemauannya sendiri. 2) Tidak terbuka baik kepada orang tuanya maupun pada gurunya, pada keadaan ini seorang anak lebih cenderung meyembunyikan masalah yang dialaminya. 3) Memiliki tanggapan negatif keadaan ini seorang anak merasa harga dirinya rendah sehingga menganggap dirinya lebih kecil dibanding orang lain. 4) Suka menarik diri keadaan diamana seorang anak lebih suka menyendiri dan menikmati dunianya sendiri. 5)Susah menerima kenyataan, dimana seorang anak tidak begitu gampang menerima akan apa yang sedang dialaminya. 6)Anak menjadi pelawak, tindakan ini merupakan seorang anak yang bermasalah untuk mencari pengakuan dan penerimaan dari dari orang lain. ${ }^{12}$

Berdasarkan pengamatan penulis pada jemaat GMIT Betania Nevo Klasis Amarasi Barat penulis melihat ada konflik yang terjadi di dalam rumah tangga Jemaat GMIT Betania Nevo Klasis Amarasi Barat, konflik itu terjadi akibat pengaruh ketidak

${ }^{7}$ Junierissa Marpaung and Kiki Dian Novitasari, "STUDI DESKRIPTIF DAMPAK ORANG TUA YANG BERKONFLIK BAGI ANAK DESCRIPTIVE STUDY OF THE IMPACT OF CONFLICTED PARENTS TOWARD CHILD," CAHAYA PENDIDIKAN 3, no. 1 (June 12, 2017), accessed May 28, 2020, https://www.journal.unrika.ac.id/index.php/journalcahayapendidikan/article/view/869.

${ }^{8}$ Isyatul Mardiyati, "DAMPAK TRAUMA KEKERASAN DALAM RUMAH TANGGA TERHADAP PERKEMBANGAN PSIKIS ANAK," RAHEEMA: Jurnal Studi Gender dan Anak (n.d.).

${ }^{9}$ Marsi Bombongan Rantesalu, GURU PENDIDIKAN AGAMA KRISTEN SEBAGAI PELOPOR REVOLUSI MENTAL, preprint (AgriXiv, October 14, 2019), accessed January 21, 2020, https://osf.io/576qt. ${ }^{10}$ Suyadi, Strategi Pembelajaran Pendidikan Karakter (PT Remaja Rosdakarya, 2013), 15.

11 Kalis Stevanus, "Tujuh Kebajikan Utama Untuk Membangun Karakter Kristiani Anak," BIA': Jurnal Teologi dan Pendidikan Kristen Kontekstual 1, no. 1 (June 30, 2018): 79-95, accessed May 28, 2020, http://www.jurnalbia.com/index.php/bia/article/view/21.

12 “6 Ciri Karakter Anak Bermasalah,” n.d., accessed May 29, 2020, http://anakceria.org/6-cirikarakter-anak-bermasalah/. 
matangan kepribadian antara suami istri, pengaruh tidak adanya kecocokan dalam hubungan yang terlanjur dibangun dan adanya masalah ekonomi dalam keluaraga, dan pengaruh intervensi keluarga besar dari salah satu pihak. Dari beberapa masalah dalam rumah tangga tersebut kemudian berpengaruh pada karakter anak yakni anak susah diatur, susah diajak kerja sama, anak bertindak semaunya sendiri, anak tidak mendengar perkataan orangtua ketika orangtua berbicara, anak selalu melawan orangtua, anak juga kurang terbuka pada orangtua. ${ }^{13}$

Permasalahan diatas membuat penulis tertarik untuk lebih mendalami permasalahan itu dan membahasnya dalam sebuah karya ilmiah mengenai pengaruh konflik rumah tangga terhadap karakter anak. Penelitian serupa tentang karakter anak pernah dilakukan oleh Rety Puspitasari dan kawan-kawan, hasilnya mengemukakan bahwa pembentukan karakter seorang anak sangat ditentukan oleh cara asuh spiritual dari ibunya. ${ }^{14}$ Penelitian yang dilakukan Anwar tentang kontribusi keluarga yang besar terhadap pembentukan karakter anak. ${ }^{15}$ dan Hasil penelitian Handreas Hartono menemukan bahwa diperlukan perjuangan dan harga yang harus dibayar oleh orang tua dalam membentuk karakter Kristen anak. Oleh sebab itu diperlukan penyerahan penuh kepada Tuhan dan juga harus dimulai dari orang tua yang terus memperbaharui diri. ${ }^{16}$

Penelitian ini berbeda dengan mereka. Penelitian-penelitian sebelumnya lebih banyak fokus ke pembentukan karakter yang banyak dipengaruhi oleh pola asuh atau kontribusi keluarga. Penelitian tersebut menggunakan penelitian dengan pendekatan kualitatif sedangkan penelitian ini menggunakan pendekatan kuantitatif. Pertanyaan dalam penelitian ini yaitu bagaimana pengaruh konflik rumah tangga terhadap karakter anak di ada di jemaat GMIT Betania Nevo Klasis Amarasi barat. Oleh karena itu tujuan penelitian ini adalah untuk mengetahui bagaimana pengaruh konflik rumah tangga terhadap karakter anak khususnya yang ada di jemaat GMIT Betania Nevo Klasis Amarasi barat

\section{Metode Penelitian}

Pada penelitian ini, peneliti menggunakan teknik penelitian dengan pendekatan kuantitatif karena peneliti akan mengumpulkan data dari populasi dalam sampel tertentu dan hasilnya dipaparkan dalam bentuk angka-angka dan statistik sebagai

\footnotetext{
${ }^{13}$ Hasil Pengamatan Penulis Selama Berada Di Tempat Itu Dan Juga Hasil Wawancara Kepada Beberapa Keluarga Dan Pendeta Yang Melayani Di Tempat Itu., n.d.

${ }^{14}$ Rety Puspitasari, Dwi Hastuti, and Tin Herawati, "PENGARUH POLA ASUH DISIPLIN DAN POLA ASUH SPIRITUAL IBU TERHADAP KARAKTER ANAK USIA SEKOLAH DASAR," Jurnal Pendidikan Karakter 0, no. 2 (2015), accessed May 28, 2020, https://journal.uny.ac.id/index.php/jpka/article/view/8624.

${ }^{15}$ Anwar Anwar, "KONTRIBUSI KELUARGA TERHADAP PEMBENTUKAN KARAKTER ANAK (Studi Perspektif Modal Sosial Di Kota Parepare)," KURIOSITAS: Media Komunikasi Sosial dan Keagamaan 9, no. 1 (2016): 57-65, accessed May 28, 2020, http://ejurnal.stainparepare.ac.id/index.php/kuriositas/article/view/175.

${ }^{16}$ Handreas Hartono, "Membentuk Karakter Kristen Pada Anak Keluarga Kristen," KURIOS (Jurnal Teologi dan Pendidikan Agama Kristen) 2, no. 1 (February 11, 2018): 62-69, accessed May 28, 2020, http://sttpb.ac.id/e-journal/index.php/kurios/article/view/22.
} 
analisis datanya. ${ }^{17}$ Penelitian dilakukan di Gereja GMIT Betania Nevo Klasis Amarasi Barat, yang berada di Kabupaten Kupang, Provinsi Nusa Tenggara Timur. Yang menjadi populasi dalam penelitian ini adalah 50 Anggota Jemaat GEMIT Betania Nevo Klasis Amarasi Barat dengan penentuan sampel menggunakan Formulasi Tabel dari Isaac Dan Michael pada taraf kesalahan 0,05 atau 5\%. Dari pengamatan pada tabel tersebut maka diperoleh jumlah sebanyak 44 orang yang dijadikan sampel.

Variabel dalam penelitian ini yaitu konflik rumah tangga sebagai variabel $\mathrm{x}$ dan karakter anak sebagai variabel Y. Pengumpulan data dilakukan dengan membagikan angket kepada sejumlah orang yang telah ditentukan (sampel). Model kuesioner yang dipakai menggunakan model likert dengan skala 1-4. Sebelum digunakan dalam penelitian, terlebih dahulu kuesioner diujicoba dengan 20 item pernyataan pada variabel X (konflik rumah tangga) dan 30 penryataan pada variabel Y (Karakter anak). Data hasil uji coba tersebut kemudian dilakukan uji validitas serta uji reliabilitas. Hasil pengujian validitas menunjukkan hasil yang menginformasikan bahwa ada 2 butir pernyataan pada variabel X yang tidak valid dan 4 butir pernyataan pada variabel $Y$. Item yang digunakan untuk penelitian adalah yang dinyatakan valid. Uji Reliabilitas dilaksanakan dengan menggunakan analisa kofesiensi Alpha Cronbach. koefesiensi relibitas pada Variabel X dengan jumlah butir valid sebanyak 18 item, menghasilkan indeks relibitas sebesar 0,907, sedangkan perhitungan pada Variabel $Y$ dengan jumlahitem yang valid sebanyak 26 butir, menghasilkan indeks reliebilitas sebesar 0,920. Adapun nilai r-tabel pada taraf signifikan sebesar $5 \%$ pada jumlah responden sebanyak 30 orang dan $\mathrm{df}=\mathrm{N}-2=28$ didapatkan nilai 0,374. Oleh sebab hasil perhitungan cronbach's Alpha lebih besar dari r-tabel maka terkonfirmasi bahwa construcht pernyataan dari variabel X (konflik rumah tangga) dan variabel Y (karakter anak) terbukti riliabel.

Data yang di peroleh dari kuesioner yang terkumpul selanjutnya dianalisis dengan langkah-langkah (prosedur)dan teknik statistik. Pengelolaan data hasil penelitian dilakukan dengan aplikasi Statistical Product and Servise Solution (SPSS) versi 22. Langkah-langkah pengelolaan data yang dimaksud dalam penelitian ini antara lain : (1) Analisisa Deskriptif. (2) Pengujian untuk persyaratan Analisis. (3) Pengujiani Hipotesis yang telah diajukan.

\section{Hasil dan Pembahasan}

\section{Hasil Penelitian}

\section{Deskripsi Data}

Setelah peneliti memperoleh hasil di lapangan kemudian data tersebut ditabulasi dalam bentuk excel kemudian dianalisa menggunakan SPSS versi 22. Output dari

${ }^{17}$ Sugiyono, Metode Penelitian Kombinasi (Bandung: Alfabeta, 2015), 11. 
perhitungan SPSS penulis uraikan melalui deskripsi data berikut ini. Deskripsi yang penulis paparkan merupakan indikator dari masing-masing variabel yaitu konflik rumah tangga (X). Dan variabel Karakter Anak (Y).

\section{Deskripsi Variabel X (Konflik Rumah Tangga)}

Penghitungan dari jumlah sampel sebanyak 44, diperoleh hasil dengan nilai rata-rata 50,14, nilai tengah 53,00, nilai yang sering muncul 57, standar deviasi 10,311, varian 106,307, range 38, nilai minimum 25, nilai makimum 63 dan total nilai sebanyak 2206. Adapun autput SPSS untuk statistik deskripsi untuk variabel konflik rumah tangga tersebut dapat dilihat dalam tabel seperti dibawah ini:

\section{Statistics}

konflik rumah tangga

\begin{tabular}{|cc|c|}
\hline $\mathrm{N}$ & Valid & 44 \\
& Missing & 0 \\
& Mean & 50.14 \\
Median & 53.00 \\
Mode & 57 \\
Std. Deviation & 10.311 \\
Variance & 106.307 \\
Range & 38 \\
Minimum & 25 \\
Maximum & 63 \\
Sum & 2206 \\
\hline
\end{tabular}

Analisis data deskripsi variabel konflik rumah tangga di atas dapat juga dilihat melalui bentuk histogram sebagai berikut:

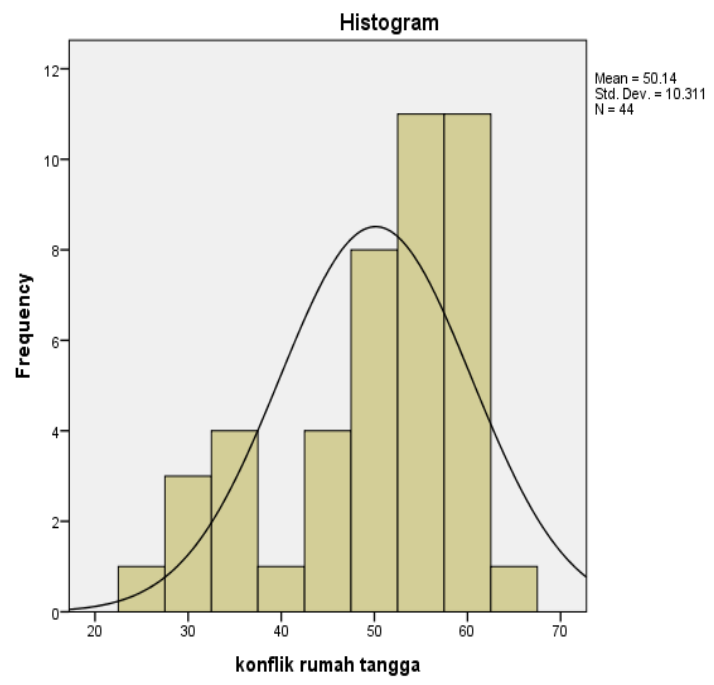

Desekripsi Variabel Y (Karakter Anak) 
Adapun hasil penghituagan pada sampel sebanyak 44 untuk variabel Y (Karakter anak) ditemukan hasil sebagai berikut: nilai rata-rata 77,09 , nilai tengah 81,00 , nilai yang sering muncul 82 , standar deviasi 11,729 , varian 137,573 , nilai range 45 , nilai minimum 47, nilai maximum 92 dan nilai total sebanyak 3392. Adapun output SPSS untuk statistik deskripsi pada variabel karakter anak tersebut bisa dilihat dalam bentuk tabel seperti berikut:

\begin{tabular}{|c|c|}
\hline \multicolumn{2}{|c|}{$\begin{array}{c}\text { Statistics } \\
\text { Karakter Anak }\end{array}$} \\
\hline Valid & 44 \\
\hline Missing & 0 \\
\hline Mean & 77.09 \\
\hline Median & 81.00 \\
\hline Mode & $82^{\mathrm{a}}$ \\
\hline Std. Deviation & 11.729 \\
\hline Variance & 137.573 \\
\hline Range & 45 \\
\hline Minimum & 47 \\
\hline Maximum & 92 \\
\hline Sum & 3392 \\
\hline
\end{tabular}

a. Multiple modes exist. The smallest value is shown

Analisis deskriptif data-data pada variabel Karakter Anak tersebut dapat juga dilihat melalui histogram berikut ini:

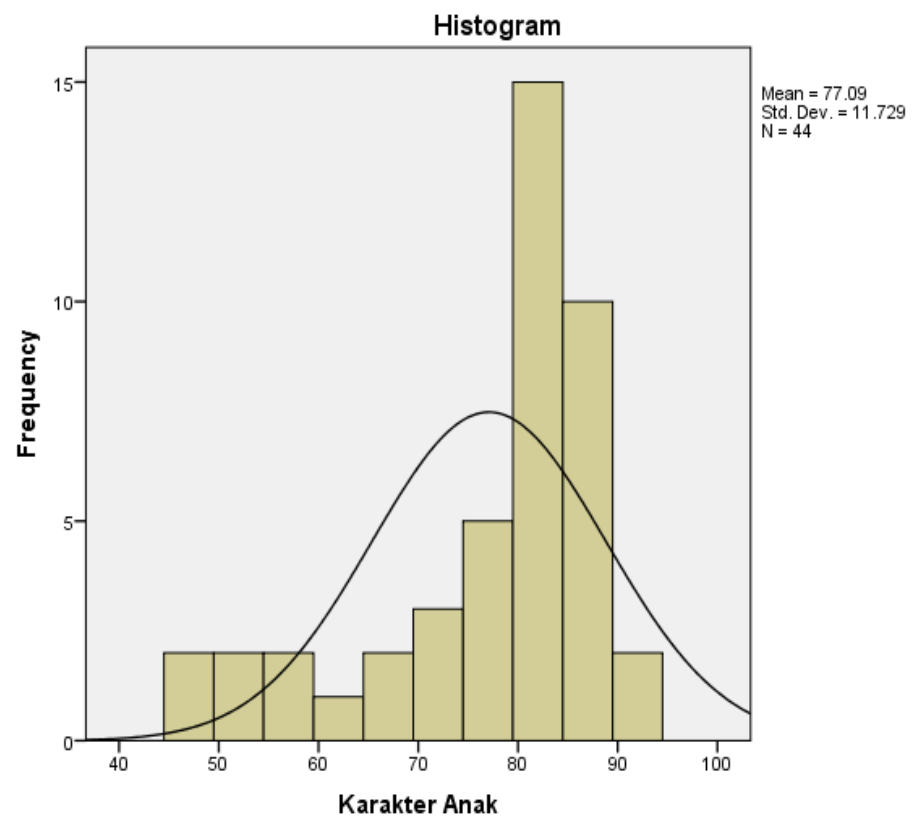




\section{Hasil Pengujian Hipotesis}

Pada pembahasan bagian ini menguraikan rangkaian pengujian yang berkaitan dengan analisi regresi sederhana. Untuk menguji hipotesis penelitian yang ada, maka yang dilakukan lebih awal adalah melakukan uji persyaratan analisis terhadap data yang telah dipaparkan sebelumnya. Adapun uji prasyarat analisis untuk dimaksud adalah pengujian normalitas data dan pengujian Linearilitas data.

Uji Normalitas

Uji normalitas dilakukan dengan tujuan untuk mengetahui apakah data dalam penelitian ini berada dalam distribusi yang normal atau justru distribusinya tidak normal. Pengujian ini diperlukan oleh karena pengujian hipotesis dengan rumus regresi sederhana dan korelasi (pengujian dengan statistic parametris) memprasyaratkan variabel X dan variabel $\mathrm{Y}$ yang akan dianalisis harus berada dalam distribusi yang normal. ${ }^{18}$

Adapun Instrumen uji normalitas yang digunakan pada perhitungan ini adalah Kolmogorov- Smirnov. Adapun kriteria normalitas dilihat dari interpretasi normal Q-Q Plots dan Normal Q-Q Plot detrended. Data dikatakan normal apabila sebaran data pada Q-Q plots berada sekitar garis lurus dan Normal Plots Q-Q Plot Detrended dikatakan normal jika sebaran titik-titik berada disekitar garis mendatar dan tidak membentuk pola tertentu. ${ }^{19}$

Hasil pengujian normalitas data ditunjukkan pada kurva berikut:

\section{Konflik Rumah Tangga}

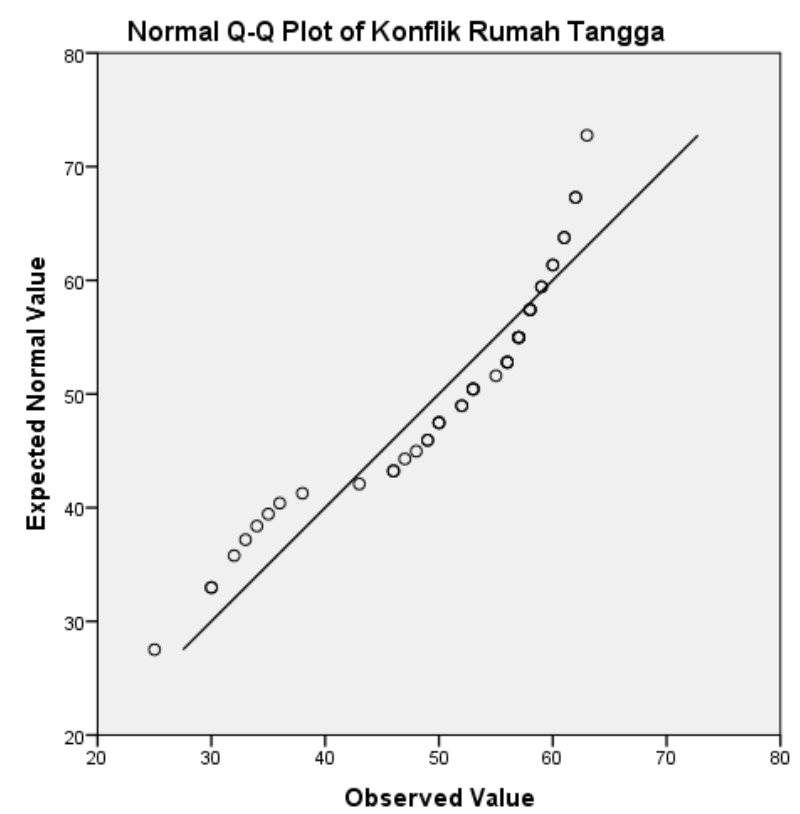

18 Ibid., 228.

${ }^{19}$ Ipin Aripin, Modul Pelatihan Analisis Data Dengan Software Excell Dan SPSS, 2008, 16. 


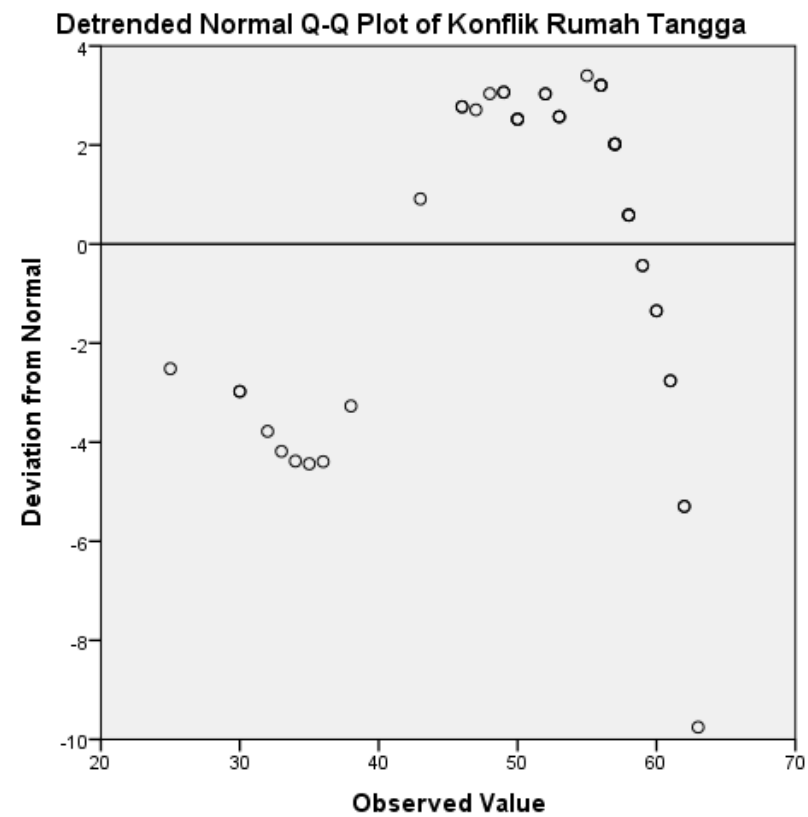

\section{Karakter Anak}

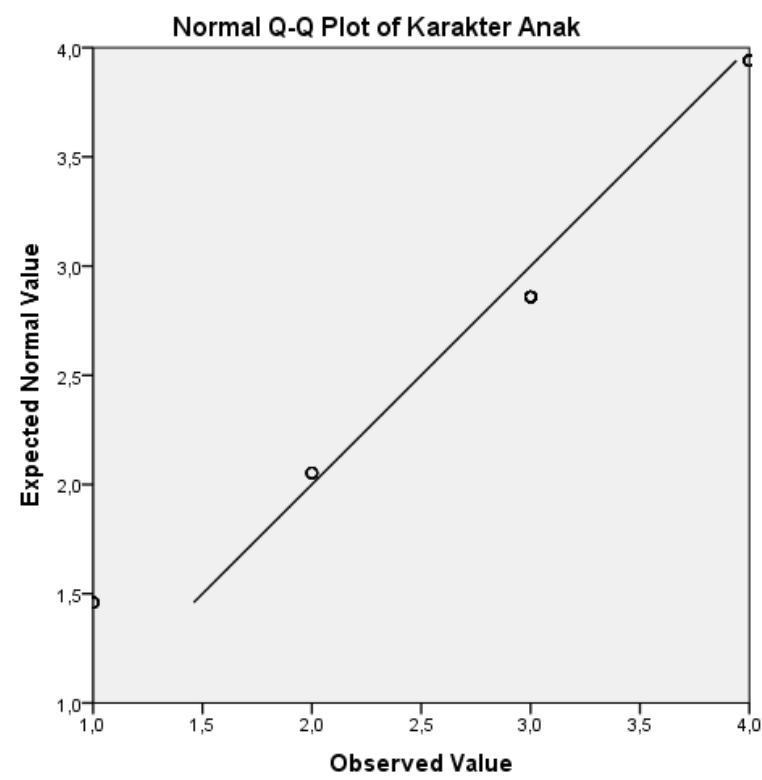




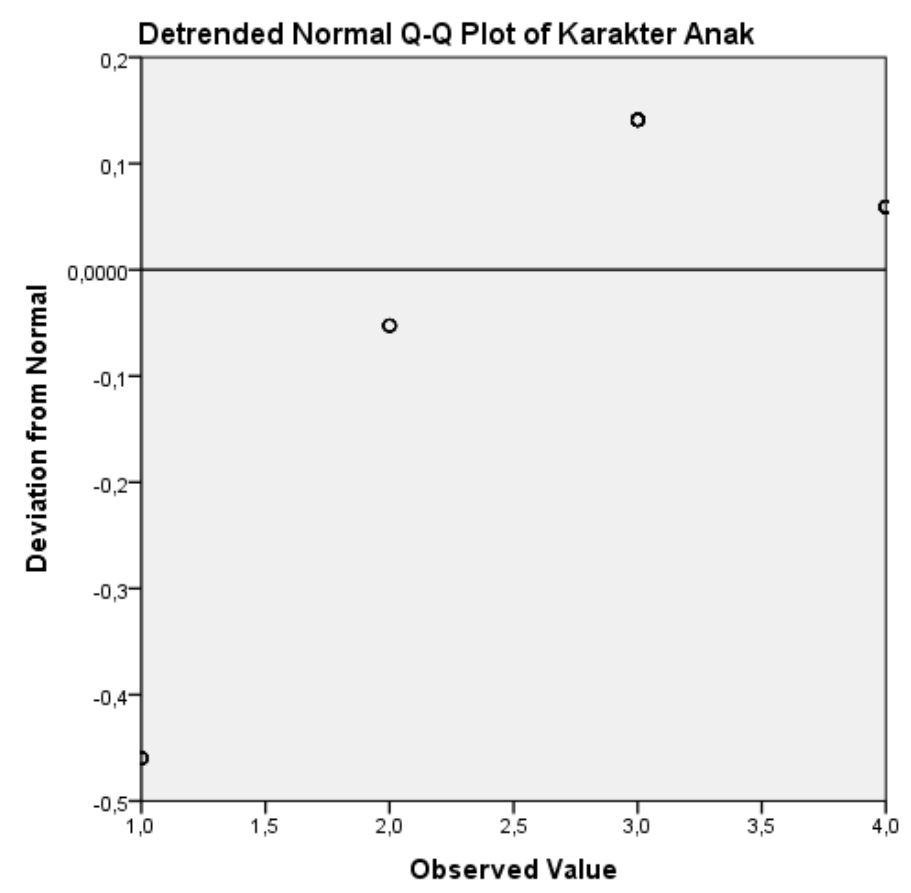

Dari normal Q-Q plots pada kedua variabel diatas terlihat toleransi normal karena sebaran titik-titik berada pada sekitar garis lurus, demikian juga detrended-nya tidak menunjukkan kurva sinus. Dengan demikian Data Variabel Konflik rumah tangga dan Karakter anak berada dalam taraf yang normal.

\section{Uji Lineritas}

Setelah semua data ada dalam distribusi yang normal maka langkas selanjutnya adalah melkukan uji linearitas. Pengujian linearitas yang dilakukan pada penelitian ini menggunakan test for linearity pada taraf signifikan 0,05 (5\%). Untuk uji linearitas ini pengambilan keputusannya adalah jika nilai signifikansi pada baris deviation from linearity untuk kedua variabel masing-masing > dari 0,05 maka dianggap linear. Pengujian linearitas ini dilakukan dengan analisis regresi yaitu pengaruh konflik rumah tangga dengan karakter anak di jemaat GMIT Betania Nevo Klasis Amarasi Barat.

Hasil Pengujian linearitas pada regresi residu varibel konflik rumah tangga (X) terhadap karakter anak (Y) diperoleh hasil sebesar 2,454 atau signifikan pada taraf $\alpha=0,068,(\alpha>0,05)$. Itu berarti bahwa hubungan antara variabel Konflik rumah tangga terhadap variabel karakter anak adalah Linear.

Hasil Uji Linearitas variabel X terhadap Y seperti yang telah dipaparkan di atas dapat dilihat dalam tabel berikut ini 
ANOVA Table

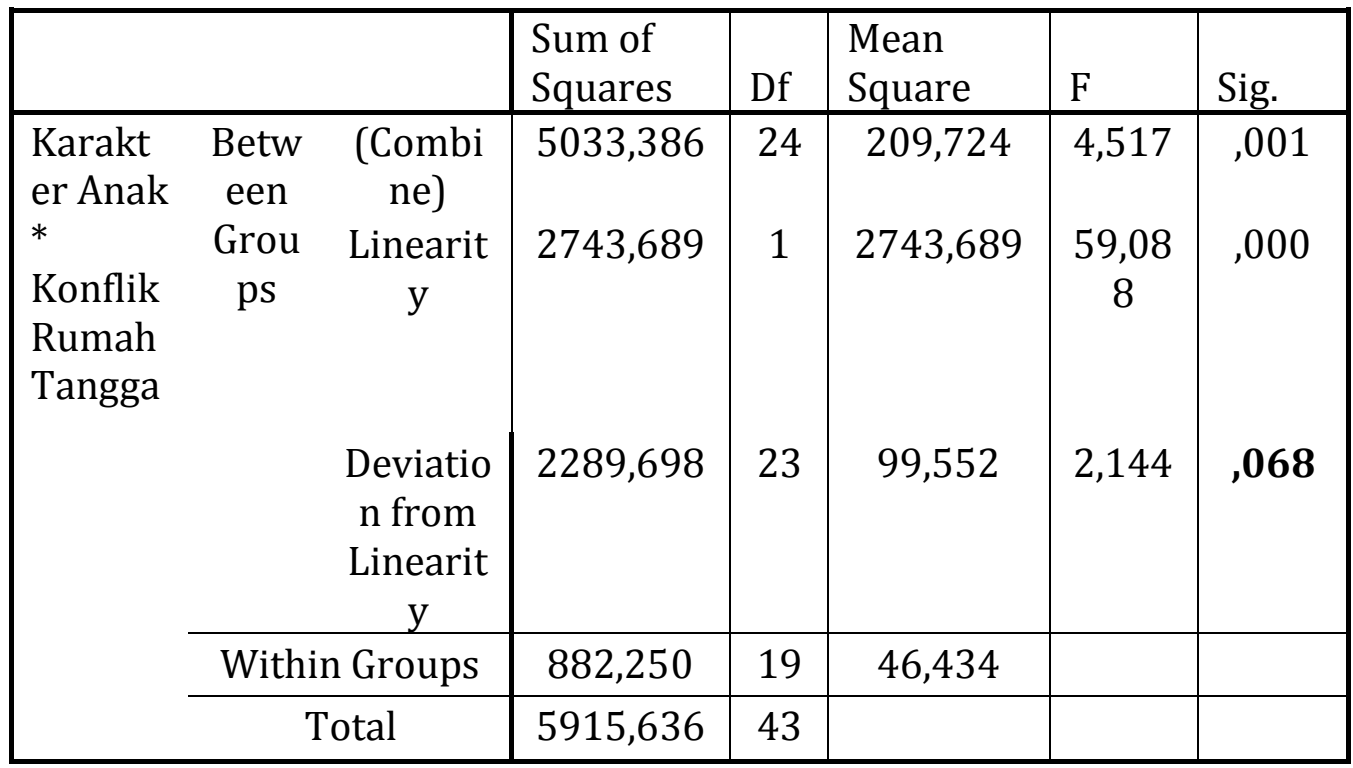

\section{Uji Homogenitas}

Pada uji homogenitas suatu data dikatakan homogen apabila:

Apabila Nilai signifikansi (p) > 0.05 menunjukkan kelompok data berasal dari populasi yang memiliki varians homogen

Apabila Nilai signifikansi (p) < 0.05 menunjukkan masing-masing kelompok data berasal dari populasi dengan varians tidak homogen

Hasil uji homogen pada penelitian ini dapat dilihat pada tabel berikut:

\begin{tabular}{|c|c|c|c|c|}
\hline & Levene Statistic & $\mathrm{df1}$ & $\mathrm{df2}$ & Sig. \\
\hline Konflik Rumah Tangga & 2.153 & 12 & 19 & .142 \\
\hline Karakter Anak & 2.692 & 12 & 19 & , 139 \\
\hline
\end{tabular}

Dari hasil pengujian tersebut dapat disimpulkan bahwa data pada penelitian ini memiliki varians yang homogen.

\section{Uji Hipotesis}

Pada penelitian ini diajukan satu hipotesis penelitian yaitu "diduga terdapat pengaruh konflik rumah tangga terhadap karakter anak di jemaat GMIT Betania Nevo Klasis Amarasi Barat".

Dari hasil pengelolaan data diperoleh hasil sebagaiman output SPSS berikut: 
Model Summary

\begin{tabular}{|c|c|c|c|c|c|}
\hline & & & & Adjusted R \\
Model & $\mathrm{R}$ & R Square & $\begin{array}{c}\text { Std. Error } \\
\text { of the } \\
\text { Estimate }\end{array}$ & $\begin{array}{c}\text { Watso } \\
\mathrm{n}\end{array}$ \\
\hline 1 & $.681^{\mathrm{a}}$ & $\mathbf{, 4 6 4}$ &, 451 & 8,690 & 1,703 \\
\hline
\end{tabular}

Predictors: (Constant), Konflik Rumah Tangga

Berdasarkan perhitungan dalam tabel di atas diperoleh nilai $R$ Squere sebesar 0,464 dari kofesien korelasi 0,681. R Square merupakan koefisien determinasi yang berarti bahwa pada penelitian ini diperoleh hasil 46,4 \% terdapat pengaruh konflik rumah tangga terhadap karakter anak di jemaat GMIT Betania Nevo Klasis Amarasi Barat. Sedangkan sisanya dapat dijelaskan oleh variabel lain atau faktor lain yang tidak diteliti pada penelitian ini. Secara umum persamaan regresi sederhana dirumuskan dengan $Y=a=+b$ X dimana:

$$
\begin{array}{ll}
\mathrm{Y} & =\text { Nilai yang diprediksikan } \\
\mathrm{a} & =\text { Konstanta atau bila } \mathrm{X}=0 \\
\mathrm{~b} & =\text { kofesiensi korelasi } \\
\mathrm{X} & =\text { Nilai Variabel Independen }
\end{array}
$$

\begin{tabular}{|c|c|c|c|c|c|c|}
\hline \multirow{2}{*}{\multicolumn{2}{|c|}{ Model }} & \multicolumn{2}{|c|}{$\begin{array}{c}\text { Unstandardize } \\
\text { d Coefficients }\end{array}$} & \multirow{2}{*}{$\begin{array}{c}\begin{array}{c}\text { Standardize } \\
\mathrm{d}\end{array} \\
\text { Coefficients } \\
\text { Beta }\end{array}$} & \multirow[b]{2}{*}{$\mathrm{T}$} & \multirow[b]{2}{*}{ Sig. } \\
\hline & & B & $\begin{array}{l}\text { Std. } \\
\text { Error }\end{array}$ & & & \\
\hline 1 & $\begin{array}{c}\text { (Consta } \\
n t)\end{array}$ & $\begin{array}{c}38,24 \\
9\end{array}$ & 6,576 & & 5,816 & ,000 \\
\hline & $\begin{array}{l}\text { Konflik } \\
\text { Rumah } \\
\text { Tangga }\end{array}$ & ,775 & 129, & 681 & 6,027 & ,000 \\
\hline
\end{tabular}

\section{Coefficients $^{\mathrm{a}}$}

a. Dependent Variable: Karakter Anak

Terlihat di tabel coefficients menunjukan nilai pada kolom signifikansi sebesar $0,000(<0,05)$ dengan demikian berarti nilai B $(38,249)$ adalah signifikan. Oleh karena itu persamaan regresi yang tepat untuk variabel X dan Variabel Y adalah:

${ }^{20}$ Sugiyono, Metode Penelitian Kombinasi, 247. 


\author{
$\mathrm{Y}=38,249+0,464 \mathrm{X}$ \\ Dengan $\mathrm{X}=$ Pengaruh Konflik Rumah Tangga \\ Y= Karakter Anak di jemaat GMIT Betani Nevo Klasis Amarasi Barat.
}

Artinya bahwa, jika indikator Konflik Rumah Tangga megalami kenaikan 1 poin maka Karakter Anak di jemaat GMIT Betania Nevo Klasis Amarasi Barat akan mengalami peningkatan sebesar 0,464 kali. Pada kolom Konstanta diperoleh nilai sebesar 38,249 yang berarti jika konflik rumah tangga adalah 0 maka karakter anak di Jemaat GMIT Betania Nevo Klasisis Amarasi Barat adalah 38,249.

Adapun hipotesis statistik yang akan diuji dalam penelitian ini adalah:

Ho: Tidak ada pengaruh konflik dalam rumah tangga terhadat karakter anak.

H1: Ada pengaruh konflik dalam rumah tangga terhadap karakter anak.

Dari hasil perhitungan pada tabel cofesient ditemukan $\mathrm{T}$ hitung $=5,816$ dengan nilai signifikansi $0,000<0,05$, dengan demikian maka Ho ditolak dan $\mathrm{H} 1$ diterima yang berarti bahwa terdapat pengaruh yang signifikan antara variabel konflik rumah tangga terhadap karakter anak di jemaat GMIT Betania Nevo Klasis Amarasi Barat.

Jadi hipotesis penelitian ini yang mengatakan bahwa diduga ada pengaruh yang signifikan variabel konflik rumah tangga (X) terhadap karakter anak (Y) terbukti dalam penelitian ini.

\title{
Pembahasan
}

Dari beberapa penelitian sebelumnya oleh Puspitasari 21 , Anwar ${ }^{22}$ dan Hartono ${ }^{23}$ menemukan bahwa konflik dalam rumah tangga itu sangat berpengaruh kepada keadaan seorang anak. Tidak terlepas dari keadaan itu merupakan karakter anak. Karakter anak yang mengalami konflik dalam rumah tangga menjadi susah diatur, susah diajak kerja sama, anak bertindak semaunya sendiri, anak tidak mendengar perkataan orangtua ketika orangtua berbicara, anak selalu melawan orangtua, anak juga kurang terbuka pada orangtua.

Indikator-indikator tersebut yang kemudian dijadikan dasar dalam penelitian ini dan telah diperoleh hasilnya yaitu: Dari Deskripsi hasil penelitian ditemukan bahwa pada variabel konflik rumah tangga jawaban responden dengan mean, 50,14, median, 53,00 mode 57 , standar deviation 10,311 , variance 106,307 , range 38 ,minimum 25 , maximum 63 dan sum 2206. Kemudian pada variabel karakter anak ditemukan mean,

\footnotetext{
21 Puspitasari, Hastuti, and Herawati, "PENGARUH POLA ASUH DISIPLIN DAN POLA ASUH SPIRITUAL IBU TERHADAP KARAKTER ANAK USIA SEKOLAH DASAR.”

${ }^{22}$ Anwar, "KONTRIBUSI KELUARGA TERHADAP PEMBENTUKAN KARAKTER ANAK (Studi Perspektif Modal Sosial Di Kota Parepare)."

${ }^{23}$ Hartono, "Membentuk Karakter Kristen Pada Anak Keluarga Kristen."
} 
77,09, median, 81,00 mode 82 , standar deviation 11,729, variance 137,573, range 45,minimum 47, maximum 92 dan sum 3392.

Berdasarkan hasil perhitungan uji persyaratan analisis regresi sederhana denga amenggunakan SPSS didapatkan hasil uji normalitas ( kolomogrov-smirnov) untuk variabel Konflik Rumah Tangga sebesar 0,297 dan pada variabel karakter anak di jemaat GMIT Betanai Nevo Klasis Amarasi Barat 0,015, karena asumsi signifikannya lebih besar dari 0,05 maka data variabel Konflik Rumah Tangga maupun Karakter Anak di jemaat GMIT Betania Nevo Klasis Amarasi Barat berdistribusi secara Normal. Berdasarkan perhitungan Uji Linearitas regresi diperoleh $\mathrm{F}$ hitung 2.144 dengan signifikan sebesar 0,068 oleh karena signifikansinya lebih besar dari 0,05 $(>0,05)$ maka dari variabel konflik rumah tangga $(\mathrm{X})$ dengan variabel karakter anak $(\mathrm{Y})$ memiliki hubungan Liniear.

Berdasarkan hasil analisis dalam penelitian ini menunjukan adanya pengaruh posetif antara konflik rumah tanga denga karakter anak di jemaat GMIT Betania Nevo Klasis Amarasi Barat, diperoleh $Y=38,249+0,464 X$ ( dari persamaaan regresi sederhana yaitu $\mathrm{Y}=\mathrm{a}+\mathrm{b} \mathrm{X}$ ) yang artinya setiap satu poin skor pada variabel konflik rumah tanga terhadap karakter anak di jemaat GMIT Betania Nevo Klasis Amarasi Barat sebesar 0,464 kali. Konstanta sebesar 38,249 artinya jika konflik rumah tangga adalah 0 maka karakter anak di jemaat GMIT betania Nevo Klasis Amarasi Barat adalah 38,249 sehingga dapat dikatakan bahwa konflik dalam rumah tangga dimaksimalkan dengan indikator-indikator yang ada didalamnya maka akan semakin besar pengaruh pada karakter anak jemaat GMIT Betania Nevo Klasis Amarasi Barat

Dari perhitungan kofesien diterminasi diketahui bahwa karakter anak di jemaat GMIT Betania Nevo Klasis Amarasi Barat di pengaruhi oleh konflik rumah tangga sebesar 46,4\% dan selebihnya dipengaruhi oleh factor-faktor lain diluar factor konflik rumah tangga yang belum diteliti oleh penulis.

\section{Kesimpulan}

Berdasarkan penelitian ini dapat disimpulkan bahwa terdapat pengaruh antara konflik rumah tangga terhadap karakter anak di GMIT jemaat Betania Nevo Klasis Amarasi Barat sebesar 46,4 \%, yang berarti bahwa masih ada faktor-faktor lain yang signifikan mempengaruhi karakter anak. Oleh karena itu direkomendasikan untuk peneliti selanjutnya untuk melakukan penelitian mencari tahu faktor-faktor tersebut. Adapun saran yang dapat penulis uraikan berdasarkan hasil penelitian ini adalah: Sebagai keluarga Kristen harus mengandalakan Tuhan dalam rumah tangga sehingga bisa meminimalisir konflik yang terjadi, orang tua memiliki tanggung jawab untuk mendidik, membimbing, menuntun dan menjadi teladan yang baik kepada anak dalam rumah tanga, orang tua harus memiliki sikap-sikap seperti penuh kasih, adil, sabar, tegas, dan memiliki kompetensi yang baik serta harus ada keterbukaan antara ayah, ibu, dan anak-anak dalam rumah tangga. 


\section{Referensi}

Anwar, Anwar. "KONTRIBUSI KELUARGA TERHADAP PEMBENTUKAN KARAKTER ANAK (Studi Perspektif Modal Sosial Di Kota Parepare)." KURIOSITAS: Media Komunikasi Sosial dan Keagamaan 9, no. 1 (2016): 57-65. Diakses 28 Mei 2020. http://ejurnal.stainparepare.ac.id/index.php/kuriositas/article/view/175.

Aripin, Ipin. Modul Pelatihan Analisis Data Dengan Software Excell Dan SPSS, 2008.

Christina, Dessy, and Andik Matulessy. "Penyesuaian Perkawinan, Subjective Well Being Dan Konflik Perkawinan.” Persona:Jurnal Psikologi Indonesia 5, no. 01 (12 Januari 2016). Diakses 28 Mei 2020. http://jurnal.untagsby.ac.id/index.php/persona/article/view/737.

Fereddy Siagian. "Figur Istri Yang Bijak Dalam Membina Rumah Tangga Kristen Bahagia Menurut Amsal 31:10-30 | Syntax Literate ; Jurnal Ilmiah Indonesia" (n.d.). Diakses 28 Mei 2020. http://www.jurnal.syntaxliterate.co.id/index.php/syntaxliterate/article/view/832.

Fincham, F.D. Stability and Change in Relationships. Boston: Cambridge University Press, 2002.

Gea, Sumaeli. "Konsep Tunduk Dan Mengasihi Berdasarkan Kolose 3:18-19 Sebagai Landasan Bagi Keutuhan Rumah Tangga Kristen di GPdI Filadelfia." Voice of HAMI: Jurnal Teologi dan Pendidikan Agama Kristen 2, no. 1 (22 oktober 2019): 60-77. Diakeses 28 Mei 2020. http://stthami.ac.id/ojs/index.php/hami/article/view/6.

Hanifah, Abu. "PERMASALAHAN KEKERASAN DALAM RUMAH TANGGA DAN ALTERNATIF PEMECAHANNYA." Sosio Konsepsia 12, no. 3 (April 10, 2017): 4556. Diakses 28 Mei 2020. https://ejournal.kemsos.go.id/index.php/SosioKonsepsia/article/view/640.

Hartono, Handreas. "Membentuk Karakter Kristen Pada Anak Keluarga Kristen." KURIOS (Jurnal Teologi dan Pendidikan Agama Kristen) 2, no. 1 (11 Februari 2018): 6269. Diakse 28 Mei 2020. http://sttpb.ac.id/ejournal/index.php/kurios/article/view/22.

Isyatul Mardiyati. "DAMPAK TRAUMA KEKERASAN DALAM RUMAH TANGGA TERHADAP PERKEMBANGAN PSIKIS ANAK.” RAHEEMA: Jurnal Studi Gender dan $\operatorname{Anak}$ (n.d.).

Marpaung, Junierissa, and Kiki Dian Novitasari. "STUDI DESKRIPTIF DAMPAK ORANG TUA YANG BERKONFLIK BAGI ANAK DESCRIPTIVE STUDY OF THE IMPACT OF CONFLICTED PARENTS TOWARD CHILD." CAHAYA PENDIDIKAN 3, no. 1 (June 12, 2017). Accessed May 28, 2020.

https://www.journal.unrika.ac.id/index.php/journalcahayapendidikan/article/vi ew/869.

Puspitasari, Rety, Dwi Hastuti, and Tin Herawati. "Pengaruh Pola Asuh Disiplin Dan Pola Asuh Spiritual Ibu Terhadap Karakter Anak Usia Sekolah Dasar.” Jurnal Pendidikan Karakter 0, no. 2 (2015). Diakses 28 Mei 2020. https://journal.uny.ac.id/index.php/jpka/article/view/8624.

Rantesalu, Marsi Bombongan. Guru Pendidikan Agama Kristen Sebagai Pelopor Revolusi Mental. Preprint. AgriXiv, 14 Oktober 2019. Diakses 21 Januari 2020. https://osf.io/576qt.

Sampe, Naomi. "Meretas Kecakapan Komunikasi Interpersonal Keluarga Kristen Memasuki Era 4.0." BIA': Jurnal Teologi dan Pendidikan Kristen Kontekstual 2, no. 
1 (June 24, 2019): 72-82. Diakses 28 Mei, 2020.

http://www.jurnalbia.com/index.php/bia/article/view/84.

Stevanus, Kalis. "Tujuh Kebajikan Utama Untuk Membangun Karakter Kristiani Anak."

BIA': Jurnal Teologi dan Pendidikan Kristen Kontekstual 1, no. 1 (30 Juni 30, 2018):

79-95. Diakses 28 Mei 28, 2020.

http://www.jurnalbia.com/index.php/bia/article/view/21.

Sugiyono. Metode Penelitian Kombinasi. Bandung: Alfabeta, 2015.

Suyadi. Strategi Pembelajaran Pendidikan Karakter. Bandung: Remaja Rosdakarya, 2013.

“6 Ciri Karakter Anak Bermasalah,” n.d. diakses 29 Mei 2020. http://anakceria.org/6ciri-karakter-anak-bermasalah/.

Hasil Pengamatan Penulis Selama Berada di Tempat Itu dan Juga Hasil Wawancara Kepada Beberapa Keluarga Dan Pendeta Yang Melayani di Tempat Itu., n.d. 